\title{
Risk Factors for Relapse and Mortality of Clostridium Difficile- Associated Diarrhea
}

\author{
Bogdan Arsic ${ }^{1}$, Momcilo Pavlovic ${ }^{2^{*}}$, Karolina Berenji ${ }^{3}$ \\ ${ }^{1}$ General Hospital Subotica - Infectious Disease Department, Subotica, Serbia; ${ }^{2}$ College of Vocational Studies, Subotica, \\ Serbia; ${ }^{3}$ Public Health Institute, Subotica, Serbia
}

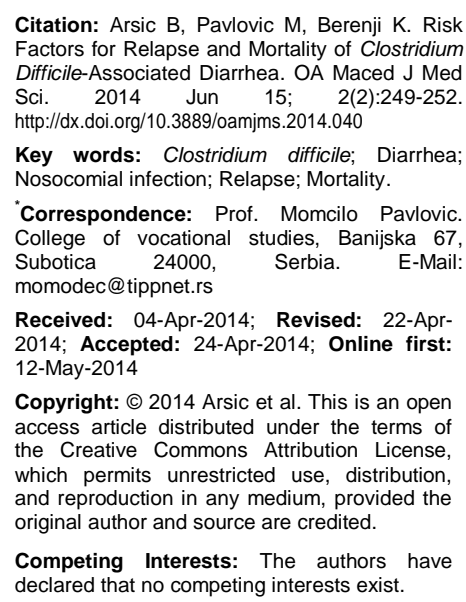

Citation: Arsic B, Pavlovic M, Berenji K. Risk Factors for Relapse and Mortality of Clostridium Difficile-Associated Diarrhea. OA Maced J Med Sci. 2014 Jun 15; 2(2):249-252 http://dx.doi.org/10.3889/oamjms.2014.040

Key words: Clostridium difficile; Diarrhea; Nosocomial infection; Relapse; Mortality.

"Correspondence: Prof. Momcilo Pavlovic. College of vocational studies, Banijska 67, Subotica 24000, Serbia. E-Mail: momodec@tippnet.rs

Received: 04-Apr-2014; Revised: 22-Apr2014; Accepted: 24-Apr-2014; Online first: 12-May-2014

Copyright: ( 2014 Arsic et al. This is an open access article distributed under the terms of the Crative Commons Attribution License, which permits which permits uniestricted use, distribution, original author and source are credited.

Competing Interests: The authors have declared that no competing interests exist.

\begin{abstract}
AIM: The aim of the present paper was to identify prognostic factors for relapse and mortality in patients with hospital-acquired infections caused by Clostridium difficile.

MATERIAL AND METHODS: This study included 133 patients with healthcare facility-associated disease caused by $C$. difficile. The medical records of all patients with their clinical history and laboratory data were analyzed.

RESULTS: Patients with one onset of disease were 105 (78.9\%), $28(21.1 \%)$ experienced a relapse and seven $(5.2 \%)$ patients not survived infection. The average age in our patients was over 65 years $(64.5$ years in the survived patients and 78.8 in patient who died, $p=0.01$ ). All of patients had received antibiotic treatment (cephalosporins - 83.4\%, aminoglycosides $-21.5 \%$ and penicillins $-20.3 \%$ ) and $40.6 \%$ of patients received acid-reducing therapy. There was no difference between patients with one onset of disease/patients with relaps; and survived/died in number of administered antibiotics, duration of administration, administration of acid-reducing treatment or length of hospital stay $(p>0.05)$. CRP levels were significantly higher in the group of patients who died compared with recovered $(p<0.001)$.
\end{abstract}

CONCLUSION: C. difficile-associated diarrhea is a common nosocomial disease with high relapse, and significant mortality rate particularly in the elderly.

\section{Introduction}

Clostridium difficile (C. difficile) is an anaerobe, Gram positive, sporogenic bacterium found in soil and intestinal tract of humans and animals. It is excreted by host through stool and the infection develops through activation of spores that are present in digestive tract or through fecal-oral pathway, by ingestion of spores found on surfaces or hands of health care staff in hospital settings [1]. C. difficile produces at least two different toxins, toxin $A$ and/or toxin $B$, both of which are cytotoxic and enteropathogenic and cause diarrhea and enterocolitis [2]. The disease usually develops after administration of antibiotics that disturb host's normal gut flora [3]. The disease may occur sporadically, but in the past few years it became epidemic in hospitals and other public health care facilities. With appropriate treatment, the disease mostly ends by restitution to health; however, recurrence may occur, while in most severe cases, death may occur as well $[1,3]$.
The aim of this paper was to analyze and compare different types of clinical course of $C$. difficile infection, and to try to identify risk factors that might influence relapse or mortality.

\section{Methods}

\section{Patients}

This retrospective study included inpatients diagnosed with $C$. difficile-associated diarrhea (CDAD) from January 1, 2009 to December 31, 2012. In all patients, the disease was identified at different departments of General Hospital Subotica, Serbia from which all of them were transferred to the Infectious Disease Department of the same hospital.

The evaluated data include age, gender and date of diagnosis. In all patients, the analyzed data included onset of complaints, duration of hospital stay, number and time of administration of antibiotics, treatment with proton pump inhibitors (PPIs) and H2 
receptors agonists, patient characteristics as risk factors (underlying illness-comorbidities, surgical procedures, endoscopy), body temperature, number and appearance of stools over 24-hour period, white blood cells (WBC) count, and C-reactive protein (CRP) levels. The above mentioned data were obtained from the medical records. In accordance with primary objective of this study, patients were classified into three groups: (1) those who responded to treatment without clinical relapse (2) patients with relapse of disease, and (3) patients who died due to disease.

\section{Definition}

Healthcare facility-associated disease: (1) the presence of diarrhea, defined as passage of 3 or more unformed stools in 24 or fewer consecutive hours; (2) patients who received antibiotics and in whom symptoms occurred at least 48 hours after hospital admission, (3) patients with positive laboratory finding of $C$. difficile A toxin and/or B toxin in stool [4].

\section{Testing for C. difficile Toxins}

The presence of $C$. difficile toxins in stool was performed using ELISA-RIDASCREEN Toxin A/B test (R-Biopharm AG, Germany).

\section{Statistical Analysis}

Categorical variables are presented as absolute and relative frequencies, whereas continuous variables are summarized as mean \pm SD . Chi-square, Z-test and Student's t-test were used for comparison of categorical and continuous variables, respectively. The rejection of the null hypothesis was set at $5 \%(P<0.05)$.

\section{Results}

The study included 133 patients, 67 (50.3\%) males and $66(49.6 \%)$ females. The average patient age was 65.3 years (range: 24.2-89.1 years). In 105 $(78.9 \%)$ patients diarrhea did not recur and 28 (21.1\%) patients experienced a relapse. Seven $(5.2 \%)$ patients died (in the group of one-episode $C$. difficile infection five and in the group with relapse two), six of seven patients who died due to toxic megacolon $(85.7 \%)$. Details concerning the hospitalization treatment, comorbidities, surgical and gastrointestinal procedures are presented in Table 1. All of the patients were treated with antibiotics. Metronidazole as monotherapy was associated with CDAD in one patient, while it was given in combination with other antibiotics in nine patients. Altogether, $33.1 \%$ of the patients were treated with more than one antibiotic.
Table 1: Some risk factors in 133 patients with CDAD.

\begin{tabular}{cc}
\hline Treatment and risks for CDAD & Number of patients (\%) \\
\hline Type of antibiotics & $111(83.4)$ \\
Cephalosporins & $28(21.0)$ \\
Aminoglycosides & $27(20.3)$ \\
Penicillins & $10(7.5)$ \\
Metronidazol & $9(6.7)$ \\
Macrolides & $7(5.2)$ \\
Fluoroquinolones & $5(3.7)$ \\
Other & \\
Number of antibiotics & $89(66.9)$ \\
1 & $29(21.8)$ \\
2 & $10(7.5)$ \\
3 & $2(1.5)$ \\
4 & $3(2.2)$ \\
$>4$ & $54(40.6)$ \\
Acid-reducing treatment & $37(27.8)$ \\
Risk factors & $28(21.0)$ \\
Post-surgery & $22(16.5)$ \\
Cancer & $10(7.5)$ \\
Diabetes mellitus & $4(3.0)$ \\
Endoscopy &
\end{tabular}

Table 2 shows toxins in stool, clinical characteristics and presentation in patients with $C$. difficile infection.

Table 2: Clinical and laboratory findings in 133 patients with CDAD.

\begin{tabular}{ll}
\hline Clinical nad laboratory findings & Number of patients $(\%)$ \\
\hline Symptoms and physical signs & \\
Mucus in stool & $30(22.5)$ \\
Rectal bleeding & $4(3.0)$ \\
Edema/ascites & $27(20.0)$ \\
Toxic megacolon & $9(6.7)$ \\
Toxins in stool & $126(94.7)$ \\
Toxin A/B & $3(2.2)$ \\
Toxin A & $4(3.0)$ \\
Toxin B & \\
\hline
\end{tabular}

Analysis that evaluated the influence of the various risk factors on patients' on recurrence end mortality is shown in Tables 3 and 4.

Table 3: Clinical and biochemical factors affecting recurrence of $C$. difficile infection.

\begin{tabular}{lccl}
\hline & $\begin{array}{c}\text { Initial CDAD (No } \\
\mathbf{1 0 5})\end{array}$ & $\begin{array}{c}\text { Recurrent Disease } \\
\text { (No 28) }\end{array}$ & $\begin{array}{l}\text { P- } \\
\text { value }\end{array}$ \\
\hline Gender male/female & $52 / 53$ & $15 / 13$ & $\mathrm{p}>0.05$ \\
Years $( \pm$ SD) & $63.5 \pm 14.9$ & $68.4 \pm 12.2$ & $\mathrm{p}>0.05$ \\
Acid-reducing treatment $(\%)$ & $45(42.8)$ & $9(33.3)$ & $\mathrm{p}>0.05$ \\
Number of antibiotics $( \pm \mathrm{SD})$ & $1.6 \pm 1.0$ & $1.3 \pm 0.6$ & $\mathrm{p}>0.05$ \\
Duration of treatment & $10.9 \pm 6.3$ & $11.3 \pm 8.0$ & $\mathrm{p}>0.05$ \\
Duration of hospital stay & $13.4 \pm 7.7$ & $12.6 \pm 8.5$ & $\mathrm{p}>0.05$ \\
CRP $(\mathrm{U} / \mathrm{L})$ & $80.3 \pm 78.8$ & $101.2 \pm 91.8$ & $\mathrm{p}>0.05$ \\
WBC $\left(\times 10^{9} / \mathrm{L}\right)$ & $13.1 \pm 8.2$ & $14.0 \pm 6.1$ & $\mathrm{p}>0.05$ \\
Number of stools & $6.78 \pm 4.4$ & $8.5 \pm 4.2$ & $\mathrm{p}>0.05$ \\
Fever $(\%)$ & $36(34.3)$ & $10(35.7)$ & $\mathrm{p}>0.05$ \\
\hline CRP - C-reactive protein; WBC - white blood cells & &
\end{tabular}

There was no significant difference in clinical and biochemical factors between patients with one onset of disease and patients who had relapse $(p>$ $0.05)$. In contrast to other characteristic, only older age of patients $(p=0.01)$ and increased CRP levels ( $p$ $<0.001$ ) were associated with high mortality rate.

\section{Discussion}

Because of its mild clinical course without complications, CDAD has traditionally been considered to be adverse effect of antibiotic therapy [5]. In the period 2004-2008, numerous reports from USA, Canada and Europe changed perception of infection by this anaerobic bacterium that became 
more aggressive, refractory to standard treatment, and with higher numbers of relapses, severe cases and higher mortality rates [6-10]. Until now, two reports have been published on $C$. difficile in Serbia: Stojanovic and Kocic presented the case of CDAD in patient after cholecystectomy, while the other was an epidemiological study by the same authors who found presence of $C$. difficile in $4 / 100$ hospitalized patients with diarrhea $[11,12]$.

Table 4. Clinical and biochemical factors affecting mortality of C. difficile infection

\begin{tabular}{lccl}
\hline & Survived (No 126) & Died (No 7) & P-value \\
\hline Gender male/female & $65 / 61$ & $2 / 5$ & $\mathrm{p}>0.05$ \\
Years $( \pm$ SD) & $64.5 \pm 14.5$ & $78.8 \pm 9.0$ & $\mathrm{p}=0.01$ \\
Acid-reducing treatment $(\%)$ & $51(40.47)$ & $3(42.8)$ & $\mathrm{p}>0.05$ \\
Number of antibiotics $( \pm \mathrm{SD})$ & $1.5 \pm 0.9$ & $1.5 \pm 0.5$ & $\mathrm{p}>0.05$ \\
Duration of treatment & $10.9 \pm 6.6$ & $10.5 \pm 3.6$ & $\mathrm{p}>0.05$ \\
Duration of hospital stay & $13.2 \pm 7.8$ & $10.7 \pm 3.6$ & $\mathrm{p}>0.05$ \\
CRP $(\mathrm{U} / \mathrm{L})$ & $85.7 \pm 82.0$ & $204.4 \pm 11.5$ & $\mathrm{p}<0.001$ \\
WBC $\left(x 10^{9} / \mathrm{L}\right)$ & $13.69 \pm 7.8$ & $30.0 \pm 30.9$ & $\mathrm{p}>0.05$ \\
Number of stools & $7.9 \pm 4.3$ & $9.8(5.0)$ & $\mathrm{p}>0.05$ \\
Fever $(\%)$ & $43(34.1)$ & $3(42.8)$ & $\mathrm{p}>0.05$ \\
\hline CRP - C-reactive protein; WBC - white blood cells & &
\end{tabular}

Although administration of virtually any antibiotic may cause development of CDAD, it usually occurs after administration of cephalosporins, wide spectrum penicillin, clindamycin and fluoroquinolones $[5,13]$. Metronidazole is rarely associated with this disease [14]. Combination of metronidazole and other antibiotics was associated with CDAD in 9 patients in this study (other antibiotics could have caused this multifactor disease in these patients, but metronidazole administration did not prevent it), while metronidazole alone was the only proven initiator of the disease in one patient.

Although the disease most commonly resolves with complete restitution to health, relapses occur in $20-25 \%$ of patients (even in $>30 \%$ of cases for the new strain), while mortality rates range from 1 $2.5 \%$ [15]. The relapse rate among patients in this study was similar $(21.1 \%)$, while mortality rates were up to two times higher $(5.2 \%)$ compared to those reported by Zilberberg et al. (2.3\%) [16]. Dallal et al. found an increase in rate of fulminant life threatening colitis from $0 \%$ in 1990 to $3.2 \%$ in 2000 [17]. From those, 44 patients underwent subtotal or total colectomy with high mortality rate of $57 \%$, while 20 patients died due to colitis. Toxic megacolon was the leading cause of death among patients in this study (6/7). Several risk or predictive factors for mortality have been described, such as old age, elevated WBC, prolonged antibiotic use of more than 4 weeks or pretreatment with three or more antibiotics [18, 19, 20]. In the present study only older age and high levels of CRP was identified as predisposing factor for mortality.

Previous studies have found numerous risk factors for relapse of CDAD, including older age, long hospital stays, and concomitant receipt of antacid medications, female gender, and additional antibiotics for treatment of other infections [21, 22]. Although our patients with relapse were on average older than those without relapse, there was no significant difference between the two groups. Older age was identified as predisposing factor only for the most severe cases ending with death.

Although the mechanism of development of recurrent $C$. difficile infection is not entirely understood, Maroo and Lamont argued that recurrence is more likely to be caused by external reinfection by $C$. difficile through feco-oral pathway than by reactivation of primary infection [23]. Longer hospital stay of patients with CDAD might additionally expose patients to spores of $C$. difficile, thus increasing the risk of disease relapse. Among patients in this study, the length of hospital stay was not identified as risk factor for disease relapse. The group of Canadian scientists from Quebec found that recurrences occurred even less commonly in patients who were hospitalized for $>30$ days [24]. Same authors concluded that re-infection has minor significance and that the main cause of recurrence is relapse of the initial disease. Among patients from different groups within this study, there was no difference in length of antibiotic treatment or number of administered antibiotics. It is likely that the main factor influencing course of the disease is host's immunological response, while antibiotic treatment and contamination by spores from hospital environment are only prerequisites for development of the disease.

Administration of $\mathrm{PPI}$, i.e. $\mathrm{H} 2$ receptors agonists, is considered to be predisposing factor for both development of the infection and for relapse, although opinions of different authors on that matter may be conflicting [25, 26]. The United States Food and Drug Administration (FDA) have recently informed the public on possible association of $C$. difficile infection and administration of PPIs [27]. The mechanism of development of the disease has been explained by disruption of hydrochloric acid barrier, delayed gastric emptying and increased level of bile salts [28]. Among patients in this study, acid-reducing treatment was not identified as predisposing factor for recurrence or death. The group of authors from various countries used rigorous selection to perform meta analysis of 47 relevant studies and found very low quality evidence on association between PPIs and C. difficile infection [29]. This opinion has been confirmed by the in vitro experiment: it has been shown on hospitalized patients, from whom gastric aspiration was collected using gastric tube, that $C$. difficile spores were not destroyed by hydrochloric acid. Furthermore, no spores germination has been shown in gastric contents of patients who received PPIs [30].

This study had several limitations. Firstly, it was a retrospective study with relatively small number of subjects. Secondly, it did not include all patients, because certain number of patients developed disease after discharge and were treated at nursing homes from which no medical records were later available. 
In conclusion, the CDAD is a significant cause of diarrhea syndrome among elderly inpatient population, but the number and duration of administered antibiotics, length of hospital stay, or acid-reducing treatment did not correlate with different types of clinical course of $C$. difficile infection. This study confirms that the hospital infection caused by $C$. difficile is present in our settings with significant rates of mortality and recurrence.

\section{References}

1. McFarland LV, Stamm WE. Review of Clostridium difficile associated diseases. Am J Infect Control. 1986;14(3):99-109.

2. Savidge TC, Pan $\mathrm{WH}$, Newman $\mathrm{P}$, O'brien $\mathrm{M}$, Anton $\mathrm{PM}$ Pothoulakis C. Clostridium difficile toxin $B$ is an inflammatory enterotoxin in human intestine. Gastroenterology. 2003;125(2):41320.

3. Barbut F, Petit JC. Epidemiology of Clostridium difficileassociated infections. Clin Microbiol Infect. 2001;7(8):405-10.

4. Cohen SH, Gerding DN, Johnson S, Kelly CP, Loo VG McDonald LC, et al. Society for Healthcare Epidemiology of America; Infectious Diseases Society of America. Clinical practice guidelines for Clostridium difficile infection in adults: 2010 update by the society for healthcare epidemiology of America (SHEA) and the infectious diseases society of America (IDSA). Infect Control Hosp Epidemiol. 2010;31(5):431-55.

5. Blossom DB, McDonald LC. The challenges posed by reemerging Clostridium difficile infection. Clin Infect Dis. 2007;45(2):222-7.

6. Noren T, Akerlund T, Bäck E, Sjöberg L, Persson I, Alriksson I, et al. Molecular epidemiology of hospitalassociated and communityacquired Clostridium difficile infection in a Swedish county. J Clin Microbiol. 2004;42(8):3635-43.

7. Cramer JP, Burchard GD, Lohse AW. [Old dogmas and new perspectives in antibiotic-associated diarrhea] Med Klin (Munich) 2008;103(5):325-38.

8 Blanckaert K, Coignard B, Grandbastien B, Astagneau P, Barbut F. Update on Clostridium difficile infections. Rev Med Interne. 2008;29(3):209-14

9. Kuijper EJ, Coignard B, Tull P. Emergence of Clostridium difficileassociated disease in North America and Europe. Clin Microbio Infect. 2006;12(Suppl 6):2-18.

10. Loo VG, Poirier L, Miller MA, Oughton M, Libman MD, Michaud $S$, et al. A predominantly clonal multi-institutional outbreak of Clostridium difficile-associated diarrhea with high morbidity mortality. N Engl J Med. 2005;353(23):2442-9.

11. Stojanovic P, Kocic B. Diarrhoea caused by Clostridium difficile in patients with postoperative subhepatic abscess. Vojnosanit Pregl. 2008;65(3):249-54

12. Kocic B, Stojanovic P. Clinical importance of Clostridium difficile finding in hospitalized patients. Med Pregl. 2008;61(11-12):632-7.

13. Kelly CP, Pothoulakis C, LaMont JT. Clostridium difficile colitis. N Engl J Med. 1994;330 (4):257-62.

14. Bignardi GE. Risk factors for Clostridium difficile infection. $J$ Hospital Infect. 1998; 40(1):1-15.

15. Bartlett JG. Clinical practice. Antibiotic-associated diarrhea. N Engl J Med. 2002; 346(5):334-9.

16. Zilberberg MD, Shorr AF, Kollef $\mathrm{MH}$. Increase in adult Clostridium difficile-related hospitalizations and casefatality rate, United States, 2000-2005. Emerg Infect Dis. 2008; 14(6):929-31.

17. Dallal RM, Harbrecht BG, Boujoukas AJ, Sirio CA, Farkas LM,
Lee KK, et al. Fulminant Clostridium difficile: an underappreciated and increasing cause of death and complications. Ann Surg 2002;235(3):363-72.

18. Walker KJ, Gilliland SS, Vance-Bryan K, Moody JA, Larsson AJ, Rotschafer JC, Guay DR. Clostridium difficile colonization in residents of long-term care facilities: prevalence and risk factors. J Am Geriatr Soc. 1993;41(9):940-6.

19. Dharmarajan T, Sipalay M, Shyamsundar R, Norkus $E$, Pitchumoni C. Co-morbidity, not age predicts adverse outcome in Clostridium difficile colitis. World J Gastroenterol. 2000;6(2):198201.

20. Lesna M, Parham DM. Risk of diarrhoea due to Clostridium difficile during cefotaxime treatment. Mortality due to $\mathrm{C}$. difficile colitis in elderly people has been underestimated. BMJ. 1996;312(7033):778.

21. Moshkowitz M, Ben-Baruch E, Kline Z, Shimoni Z, Niven M, Konikoff F. Risk factors for severity and relapse of pseudomembranous colitis in an elderly population. Colorectal Dis. 2007;9(2):173-7

22. Barbut F, Richard A, Hamadi $K$ et al. Epidemiology of recurrences or reinfections of Clostridium difficile-associated diarrhea. J Clin Microbiol. 2000;38(6):2386-8.

23. Maroo S, Lamont JT. Recurrent clostridium difficile. Gastroenterology. 2006;130(4): 1311-6.

24. Pepin J, Alary ME, Valiquette L, Raiche E, Ruel J, Fulop K, et al. Increasing risk of relapse after treatment of clostridium difficile colitis in Quebec, Canada. Clin Infect Dis. 2005;40(11):1591-7.

25. Johnson S. Recurrent Clostridium difficile infection: a review of risk factors, treatments, and outcomes. Journal of Infection. 2009;58(6):403-10.

26. Hookman P, Barkin J. Clostridium difficile associated infection, diarrhea and colitis. World J Gastroenterol. 2009;15(13):1554-80.

27. Elixhauser A, Jhung M. Clostridium Difficile-Associated Disease in U.S. Hospitals, 1993-2005. HCUP Statistical Brief \#50 April 2008. Agency for Healthcare Research and Quality, Rockville MD. Available http://www.hcupus.ahrq.gov/reports/statbriefs/sb50.pdf.

28. Jump RL, Pultz MJ, Donskey CJ. Vegetative Clostridium difficile survives in room air on moist surfaces and in gastric contents with reduced acidity: a potential mechanism to explain the association between proton pump inhibitors and $\mathrm{C}$. difficile-associated diarrhea? Antimicrob Agents Chemother. 2007;51(8):2883-7.

29. Tleyjeh IM, Bin Abdulhak AA, Riaz M, Alasmari FA, Garbati MA, AlGhamdi $M$, et al. Association between proton pump inhibitor therapy and clostridium difficile infection: a contemporary systematic review and meta-analysis. PLoS One. 2012;7(12):e50836.

30. Nerandzic MM, Pultz MJ, Donskey CJ. Examination of potential mechanisms to explain the association between proton pump inhibitors and Clostridium difficile infection. Antimicrob Agents Chemother. 2009;53(10):4133-7. 